\title{
Macro-Micromorphological, Antioxidant and Preliminary Phytochemical Studies on Two Terrestrial Orchids Eulophia Nuda Lindl. and Geodorum Densiflorum (Lam.) Schltr.
}

\author{
Dasgupta $\mathbf{R}^{*}$, Dongarwar NM \\ Department of Botany, RTM Nagpur University, Nagpur, Maharashtra, India
}

Received June 11, 2020; Revised October 8, 2020; Accepted January 23, 2021

\begin{abstract}
Cite This Paper in the following Citation Styles
(a): [1] Dasgupta R, Dongarwar NM, "Macro-Micromorphological, Antioxidant and Preliminary Phytochemical Studies on Two Terrestrial Orchids Eulophia Nuda Lindl. and Geodorum Densiflorum (Lam.) Schltr.," Advances in Zoology and Botany, Vol. 9, No. 2, pp. 45 - 51, 2021. DOI: 10.13189/azb.2021.090202.
\end{abstract}

(b): Dasgupta R, Dongarwar NM (2021). Macro-Micromorphological, Antioxidant and Preliminary Phytochemical Studies on Two Terrestrial Orchids Eulophia Nuda Lindl. and Geodorum Densiflorum (Lam.) Schltr.. Advances in Zoology and Botany, 9(2), 45 - 51. DOI: 10.13189/azb.2021.090202.

Copyright@2021 by authors, all rights reserved. Authors agree that this article remains permanently open access under the terms of the Creative Commons Attribution License 4.0 International License

\begin{abstract}
An attempt for study of two terrestrial orchids i.e. Eulophia nuda (Lindl.) and Geodorum densiflorum (Lam.) Schltr. were carried out. Main focus was on the corms of both the orchids due to its huge medicinal properties like anticancerous, antioxidant, antidiabetic, antimicrobial, phytotoxic, etc. This is one of the prime reasons behind their threatened status along with endemic habitat. The parameters which were analysed during the study include macro- and micro-morphology, preliminary phytochemistry, and antioxidant activity (DPPH activity). In macro-morphology of both the orchids, slight difference was reported and, thus sometimes Geodorum densiflorum is being used as an adulterant in place of Eulophia nuda. During micro-morphological analysis, the oxalate crystals, raphides, mucilage ducts, starch grains, and oil granules were observed from cortical region of corm and in the mesophyll tissue of leaves in both the orchids. Stomatal Index of leaf surface was calculated along with the type of stomata, i.e. Cyclic II type. Preliminary analysis of phytochemical constituents in both the orchids was performed with three different solvent systems. A comparative antioxidant activity between leaves extract of both the orchids was carried out.
\end{abstract}

Keywords Orchid, Amarkand, Epigynous, Macro-Micromorphological, Stomata, Medicinal Properties, Preliminary Phytochemistry, Antioxidant
Activity, DPPH Free Radical Scavenging Assay

\section{Introduction}

The two taxa under investigation belong to the family Orchidaceae, which is one of the largest and diversified families among angiosperms [1].

a). Eulophia nuda Lindl (= E. spectabilis (Dennst.) Suresh) a terrestrial orchid, which usually grows in shady places alongwith grasses and shrubs in forests. In ayurveda, it is known as Amarkand [2]. Its corms are medicinally important and are used for curing bronchitis, tumours, scrofulous glands, and also used as vermifuge. Anticancerous, anti-oxidant, and antibiotic properties are reported $[3,4,5]$. Due to overexploitation, it is under threatened status. Due to the similar morphology of their corms, Geodorum densiflorum corms are used as adulterant.

b). Geodorum densiflorum (Lam.) Schltr. is mostly found in wet habitats like rainforests, moist deciduous forests, and grasslands with mostly terrestrial habit. In India, it is distributed in Kerala, Karnataka, Tamil Nadu and Maharashtra [6]. The corm extracts also shows antioxidant, cytotoxic, and 
antibacterial potentials [7, 8].

In orchids, the flower is modified and diversified among the angiosperms such as zygomorphic flowers, which show variously modified labellum, epigyny, reduced stamens adhering with style and stigma to form a column (Gynandrium), pollens bound together to form a mass called as pollinia. Orchid seeds are very minute [9]. The underground fibrous corms contain important secondary metabolites like triterpenoids/steroids, saponins, proteins, anthraquinones, anthocyanins, etc $[10,1]$. Out of these phenanthrene derivatives are isolated from corms of Eulophia nuda i.e. Nudol possess anti-cancerous, antioxidant, and antimicrobial, anti-inflammatory, antiallergic, phytotoxic properties [4, 11]. Phenanthrenes are tricyclic aromatic hydrocarbon (isomeric with anthracene) insoluble in water but soluble in most organic solvents like toluene, carbon tetrachloride, ether, chloroform, acetic acid, and benzene [11].

\section{Materials and Methods}

\subsection{Collection of Plants}

Primary step was scanning of probable regions for the availability of these two orchids- Eulophia nuda and Geodorum densiflorum. Eulophia was collected from Kolhapur and Melghat forest, Amravati; while Geodorum from Ghodazari forest (Chandrapur District) and Rawanwadi, (Bhandara District). The collected plants were identified with the help of standard literature like Flora of Maharashtra and Flora of Kolhapur [12].

\subsection{Morphological Characterization}

\subsubsection{Macroscopic characters}

Macro-morphological characters of stem, leaf, and corm were analysed and compared between the two orchids manually. Observed differentiating characters were noted.

\subsubsection{Microscopic characters}

For micro-morphological characters, thin transverse sections of fresh leaves and corms were taken and dipped in $70 \%$ ethanol for 2 minutes, stained with safranin for 30 minutes and then dehydrated at $95 \%$ ethanol plus $0.5 \%$ picric acid for 30 seconds. Then sections were washed with 95\% ethanol and 4 drops ammonium hydroxide per $100 \mathrm{~mL}$ for 30 seconds. For final dehydration step dipped the sections in absolute alcohol for 10 seconds. Later counterstained with Fast green and washed with absolute alcohol to remove excessive stain. At last kept the slides in xylene solution for 20 seconds and mounted in glycerine then observed under microscope (Johansen, 1940) [13].

\subsection{Preliminary Phytochemistry}

The leaves and corms of both the orchids were dried and crushed for preliminary phytochemical analysis. Three different solvent systems were used for comparative study as used by Maurya and Dongarwar, 2009 [14]. All the preliminary phytochemical tests were performed according to the methods given by Sadasivam and Manickam, 1996 [15]; and Harborne, 1973 [16].

\subsection{Antioxidant Analysis}

\section{DPPH Free Radical Scavenging Assay}

In vitro antioxidant activity of the sample extracts analysed via DPPH (2, 2-diphenyl-1-picrylhydrazyl) free radical assay [17]. The sample stocks were diluted with methanol to prepare a concentration series of $25 \mu \mathrm{L}, 50 \mu \mathrm{L}$, $75 \mu \mathrm{L}, 100 \mu \mathrm{L}$, and $125 \mu \mathrm{L}$. DPPH solution prepared by adding $1.3 \mathrm{mg} / \mathrm{mL}$. To each concentration series $75 \mu \mathrm{L}$ DPPH solution was added, shaken vigorously, and kept under dark for 30 minutes at room temperature. The decoloration of DPPH was determined by measuring the absorbance at 517nm using Shimudzu UV 1800 spectrophotometer. The percentage of scavenging is calculated by the following equation.

$$
\text { DPPH Scavenged (\%) }=A_{\text {control }}-A_{\text {test }} / A_{\text {control }} \times 100
$$

\section{Results}

\subsection{A. Macroscopic Characters}

Stem of Eulophia is greenish yellow and that of Geodorum is green in color. Leaves are membranous; leaf surface is smooth in Geodorum whereas it is rough in Eulophia. Both the orchids have fibrous underground corms. In Eulophia, the corm shape is ovoid while, in Geodorum it is sub-globose. Size of tuber in Eulophia nuda is 3.5-4 cm (Figure 2); in Geodorum densiflorum around 3-3.5 cm (Figure 1).

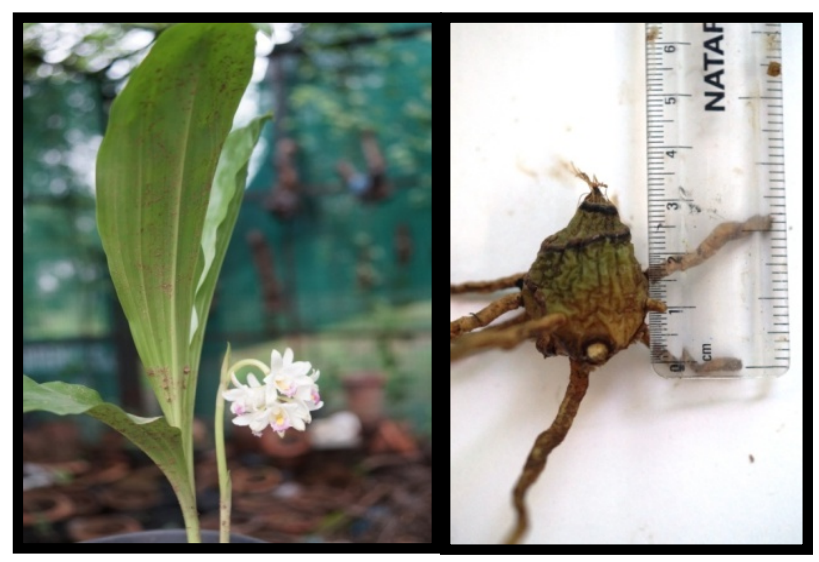

Figure 1. Geodorum densiflorum and its corm. 


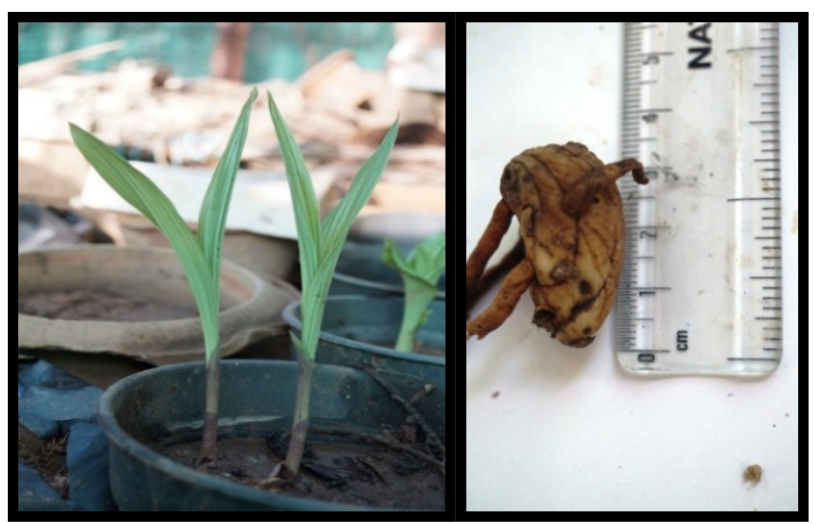

Figure 2. Eulophia nuda and its corm

\subsection{B. Microscopic Characters}

For studying micro characters of Eulophia nuda and
Geodorum densiflorum, thin sections of corm, roots, and leaf were taken.

Corm: The section of both the orchids shows epidermis with multilayered velamen tissue (Figure 3A). In ground tissue, oxalate crystals, mucilage ducts, starch grains, oil granules, raphides, and scattered conjoint closed vascular bundles are present (Figure 3 A, B, C, D, F, G, H).

Leaf: It shows thin layer epidermis surrounding mesophyll tissue containing oil granules, raphides, and closed vascular bundles (Figure $3 \mathrm{E}, \mathrm{I}, \mathrm{J}$ ). Xylem and phloem are enclosed by sclerenchymatous bundle sheath cells (Figure $3 \mathrm{~K}$ ).

Stomata: Stomata in both the orchids is of Cyclic II type, where there are four epidermal cells, two are elongated and parallel to the long axis of the guard cells while the other two are short and rectangular cells (Figure $3 \mathrm{~L}$ ).
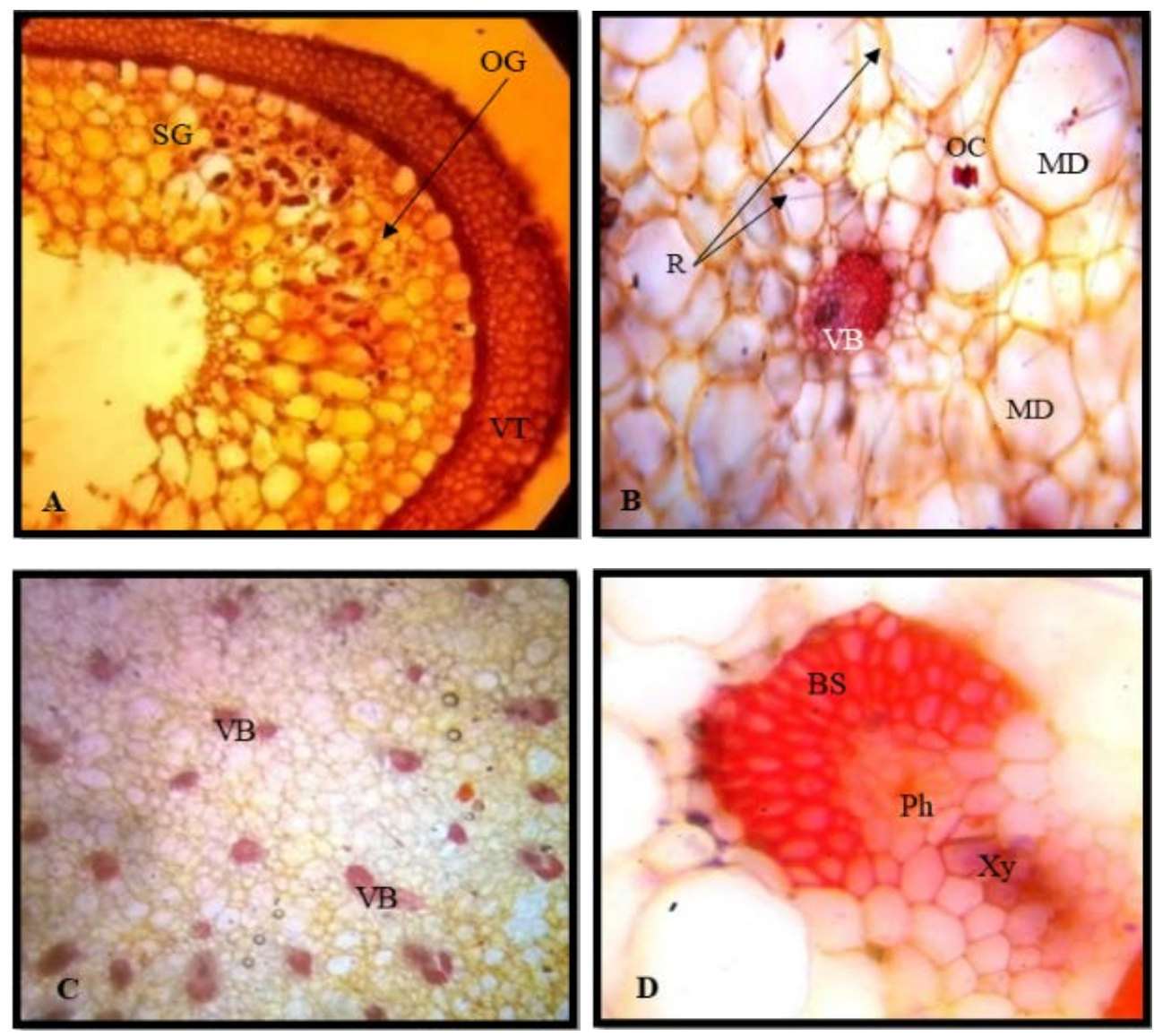

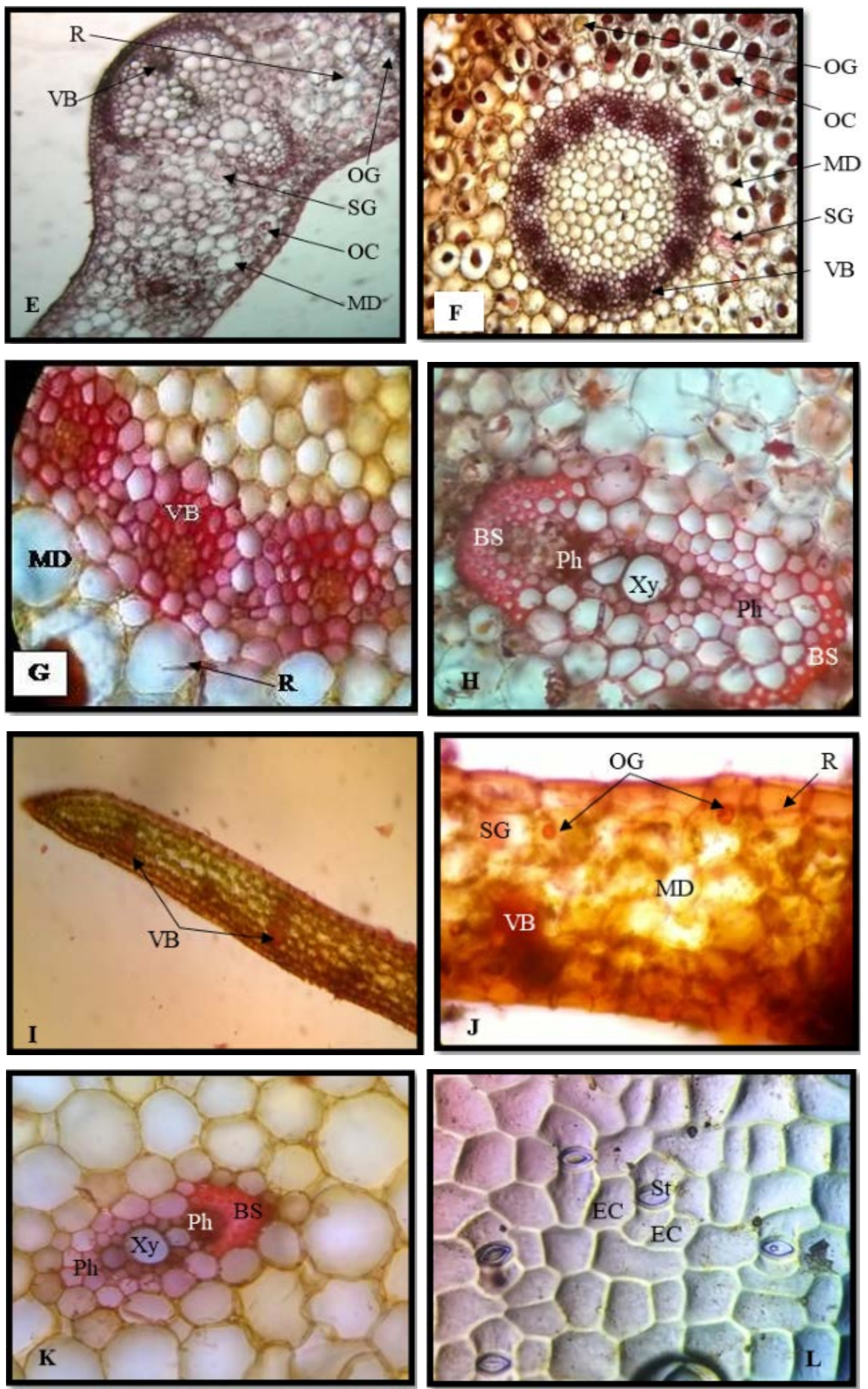

VT- Vilamen tissue, OG- Oil granule, OC- Oxalate crystal, MD- Mucilage duct, R- Raphides, VB- Vascular bundle, BS- Bundle sheath, Ph- Phloem, Xy- Xylem, SG- Starch grain, EC- Epidermal cells, St- Stomata.

Figure 3. A) T.S. of Eulophia nuda corm; B) Enlarged view with mucilage ducts, raphides, oxalate crystals and vascular bundles; C) T.S. of Eulophia nuda root with scattered vascular bundles; D) An enlarged conjoint closed vascular bundles enclosed by bundle sheath cells. E) T.S. of Eulophia nuda leaf with detailed view; F) T.S. of Geodorum densiflorum corm showing oxalate crystals (dark colored), oil granules, mucilage ducts, raphides, and vascular bundles ; G) Enlarged view; H) Single vascular bundle; I) T.S. of Geodorum densiflorum leaf ; J) Detailed view of the section; K) An enlarged vascular bundle, L) Stomata type of both the orchids. 


\section{Stomatal Index}

Stomatal distributions on upper and lower leaf surface were calculated through stomatal index. The stomatal index is calculated by following formula:

Stomatal Index $=$ No. of stomata per $\mathrm{mm}^{2}$ x $100 \div$ No. of stomata per $\mathrm{mm}^{2}+$ No. of epidermal cells per $\mathrm{mm}^{2}$.

According to the data presented in table 1 the lower leaf surface of Eulophia nuda shows 30.95\% stomatal index and that of Geodorum densiflorum shows 29.26\%. Whereas the upper leaf surface of both the orchids show zero stomatal index which indicates absence of stomata inspite of leaf being isobilateral.

\subsection{Preliminary Phytochemical Analysis}

The preliminary chemical tests of the leaf powder were carried out with three different solvents. Flavonoids, proteins, tannins, carbohydrates, phenols, quinones, terpenoids and steroids were present in all the three extracts of both the orchids. While saponins and anthocyanins were confirmed from methanolic and water extract of both the orchids; volatile oils from petroleum ether extract only of both the orchids. Few chemicals were completely absent in all the extracts like cardiac glycosides, anthrene glycosides, and coumarins (Table 2).

Table 1. Stomatal distribution on upper and lower leaf surfaces of both the orchid.

\begin{tabular}{|c|c|c|c|c|c|c|c|}
\hline \multirow[t]{2}{*}{ S.No. } & \multirow[t]{2}{*}{ Name of Plant } & \multicolumn{3}{|c|}{ Lower Stomata } & \multicolumn{3}{|c|}{ Upper Stomata } \\
\hline & & $\begin{array}{c}\text { No. of Epidermal } \\
\text { cells }\end{array}$ & $\begin{array}{c}\text { No. of } \\
\text { Stomata }\end{array}$ & Stomatal Index & $\begin{array}{c}\text { No. of Epidermal } \\
\text { cells }\end{array}$ & $\begin{array}{c}\text { No. of } \\
\text { Stomata }\end{array}$ & $\begin{array}{c}\text { Stomatal } \\
\text { Index }\end{array}$ \\
\hline \multirow[t]{2}{*}{1} & Eulophia nuda & $\begin{array}{l}249 \\
273 \\
255 \\
289 \\
319 \\
\end{array}$ & $\begin{array}{l}105 \\
103 \\
114 \\
145 \\
154 \\
\end{array}$ & 30.95 & $\begin{array}{l}289 \\
205 \\
321 \\
307 \\
297 \\
\end{array}$ & $\begin{array}{l}0 \\
0 \\
0 \\
0 \\
0 \\
\end{array}$ & 0 \\
\hline & & Average $=277$ & $\begin{array}{c}\text { Average }= \\
124.2\end{array}$ & & Average = 283.8 & & \\
\hline \multirow[t]{2}{*}{2} & $\begin{array}{l}\text { Geodorum } \\
\text { densiflorum }\end{array}$ & $\begin{array}{l}289 \\
205 \\
321 \\
307 \\
297 \\
\end{array}$ & $\begin{array}{l}109 \\
116 \\
129 \\
120 \\
113 \\
\end{array}$ & 29.26 & $\begin{array}{l}167 \\
227 \\
169 \\
133 \\
149 \\
\end{array}$ & $\begin{array}{l}0 \\
0 \\
0 \\
0 \\
0 \\
\end{array}$ & 0 \\
\hline & & Average = 283.8 & $\begin{array}{c}\text { Average }= \\
117.4\end{array}$ & & Average $=169$ & & \\
\hline
\end{tabular}

Table 2. The preliminary phytochemical observations

\begin{tabular}{|c|c|c|c|c|c|c|c|}
\hline \multirow[t]{2}{*}{ Phytochemicals } & \multirow[t]{2}{*}{ Chemical tests } & \multicolumn{2}{|c|}{$\begin{array}{c}\text { Petroleum ether } \\
\text { extract }\end{array}$} & \multicolumn{2}{|c|}{$\begin{array}{c}\text { Methanol } \\
\text { extract }\end{array}$} & \multicolumn{2}{|c|}{$\begin{array}{c}\text { Water } \\
\text { Extract }\end{array}$} \\
\hline & & E. n. & G. d. & E. n. & G. d. & E. n. & G. d. \\
\hline \multirow[t]{2}{*}{ Flavonoids } & Alkaline Reagent test & + & + & + & + & + & + \\
\hline & Lead Acetate test & + & + & + & + & + & + \\
\hline \multicolumn{2}{|c|}{ Terpenoids and Steroids } & + & + & + & + & + & + \\
\hline Proteins & $\begin{array}{c}\text { a) Biuret Reaction } \\
\text { b) Xanthoproteic Reaction }\end{array}$ & $\begin{array}{l}+ \\
+ \\
\end{array}$ & $\begin{array}{l}+ \\
+ \\
\end{array}$ & $\begin{array}{l}+ \\
+\end{array}$ & $\begin{array}{l}+ \\
+ \\
\end{array}$ & $\begin{array}{l}+ \\
+ \\
\end{array}$ & $\begin{array}{l}+ \\
+ \\
\end{array}$ \\
\hline Tannin & $\begin{array}{l}\text { a) Ferric Chloride test } \\
\text { b) Lead Acetate test }\end{array}$ & $\begin{array}{l}+ \\
+ \\
+\end{array}$ & $\begin{array}{l}+ \\
+ \\
+\end{array}$ & $\begin{array}{l}+ \\
+ \\
\end{array}$ & $\begin{array}{l}+ \\
+ \\
\end{array}$ & $\begin{array}{l}+ \\
+ \\
+\end{array}$ & + \\
\hline $\begin{array}{l}\text { Carbohydrates } \\
\text { (reducing sugar) }\end{array}$ & $\begin{array}{l}\text { a) Fehling's test } \\
\text { b) Benedict's test } \\
\text { c) Barfoed's test }\end{array}$ & $\begin{array}{l}+ \\
+ \\
+\end{array}$ & $\begin{array}{l}+ \\
+ \\
+\end{array}$ & $\begin{array}{l}+ \\
+ \\
+\end{array}$ & $\begin{array}{l}+ \\
+ \\
+\end{array}$ & $\begin{array}{l}+ \\
+ \\
+\end{array}$ & $\begin{array}{l}+ \\
+ \\
+ \\
\end{array}$ \\
\hline Phenols & & + & + & + & + & + & + \\
\hline \multicolumn{2}{|c|}{ Cardiac glycosides } & - & - & - & - & - & + \\
\hline \multicolumn{2}{|c|}{ Anthrene glycosides } & - & - & - & - & - & - \\
\hline \multicolumn{2}{|c|}{ Saponins } & - & - & + & + & + & + \\
\hline \multicolumn{2}{|c|}{ Anthocyanins } & - & - & + & + & + & + \\
\hline \multicolumn{2}{|c|}{ Coumarins } & - & - & - & - & - & - \\
\hline \multicolumn{2}{|c|}{ Quinones } & + & + & + & + & + & + \\
\hline \multicolumn{2}{|c|}{ Volatile oils } & + & + & - & - & - & - \\
\hline
\end{tabular}




\subsection{Antioxidant Analysis}

\section{DPPH Free Radical Scavenging Assay}

Free radical scavenging activity of petroleum ether and methanolic extracts of Eulophia nuda and Geodorum densiflorum leaves were measured by 1 , 1-diphenyl-2-picryl hydrazyl (DPPH). Ascorbic acid was used as the standard reference compound. Lower absorbance of the sample extract indicated higher free radical activity (Table 3, 4). Here control absorbance was of DPPH (0.632).

Table 3. Absorbance of PE (Petroleum ether) and M (Methanol) extract of Geodorum densiflorum and Eulophia nuda at $517 \mathrm{~nm}$ by UV-Visible Spectrophotometer (DPPH assay).

\begin{tabular}{|c|c|c|c|c|c|}
\hline $\begin{array}{c}\text { Conc. } \\
(\mu \mathrm{g} / \mathrm{mL})\end{array}$ & $\begin{array}{c}\text { Ascorbic } \\
\text { acid }\end{array}$ & P E (E.n.) & $\begin{array}{c}\text { P E } \\
\text { (G.d.) }\end{array}$ & $\begin{array}{c}\mathrm{M} \\
(\text { E.n. })\end{array}$ & $\begin{array}{c}\mathrm{M} \\
(\mathrm{G} . \mathrm{d} .)\end{array}$ \\
\hline 5 & 0.707 & 0.255 & 0.35 & 0.097 & 0.621 \\
\hline 10 & 0.51 & 0.198 & 0.25 & 0.095 & 0.613 \\
\hline 15 & 0.38 & 0.086 & 0.21 & 0.092 & 0.473 \\
\hline 20 & 0.044 & 0.083 & 0.15 & 0.071 & 0.413 \\
\hline 25 & 0.041 & 0.064 & 0.12 & 0.063 & 0.406 \\
\hline 30 & 0.042 & 0.057 & 0.09 & 0.037 & 0.404 \\
\hline
\end{tabular}

Table 4. Showing \% inhition of different PE (Petroleum ether) and $\mathrm{M}$ (Methanol) extract of Eulophia nuda and Geodorum densiflorum leaves with ascorbic acid as standard.

\begin{tabular}{|c|c|c|c|c|c|}
\hline $\begin{array}{c}\text { Conc. } \\
(\mu \mathrm{g} / \mathrm{mL})\end{array}$ & $\begin{array}{c}\text { Ascorbic } \\
\text { acid }\end{array}$ & $\begin{array}{c}\text { PE } \\
(\text { E.n. })\end{array}$ & $\begin{array}{c}\text { PE } \\
(\mathrm{G} . d .)\end{array}$ & $\begin{array}{c}\text { M } \\
(\text { E.n. })\end{array}$ & M (G.d.) \\
\hline 5 & 7.94 & 59.65 & 45.98 & 84.65 & 1.74 \\
\hline 10 & 33.59 & 68.67 & 60.44 & 84.96 & 3.01 \\
\hline 15 & 50.52 & 86.39 & 66.77 & 85.44 & 25.11 \\
\hline 20 & 94.27 & 86.86 & 76.26 & 88.76 & 34.65 \\
\hline 25 & 94.66 & 89.87 & 81.01 & 90.03 & 35.75 \\
\hline 30 & 94.53 & 90.98 & 85.75 & 94.14 & 36.07 \\
\hline
\end{tabular}

\section{Conclusions}

In the present investigation, a detailed macro-micromorphological characteristics were studied, which revealed the difference in appearance of corm, stem, leaves in both the orchids. Micro-morphology revealed the internal arrangement of cells and presence of various substances like oil granules, oxalate crystals, starch grains, mucilage ducts. Transverse section of corm shows the presence of scattered closed vascular bundles enclosed by sclerenchymatous bundle sheath cells. The preliminary phytochemical study of leaf powder using three different solvent systems revealed the presence of flavonoids, terpenoids/steroids, proteins, tannins, carbohydrates, phenols, and quinones in all the three solvent systems. While volatile oils were observed only in petroleum ether extract; anthocyanins and saponins were observed in methanol and distilled water extracts. The antioxidant activity was analysed by DPPH free radical scavenging assay with ascorbic acid as standard compound which showed better scavenging \% in Eulophia nuda than Geodorum densiflorum in both petroleum ether and methanol extracts.

\section{REFERENCES}

[1] Chachad DP, Jagdale SP. 2015.Pharmacognostical standardisation of Eulophia nuda Lindl. World Journal of Pharmaceutical Research. Vol 4.

[2] Narkhede AN, Kasote DM, Kuvalekar AA, Harsulkar AM, Jagtap SD. 2016. Amarkand: A comprehensive review on its ethnopharmacology, nutritional aspects, and taxonomy. Journal of Intercultural Ethanopharmacology. 5(2): 198-204.

[3] Bhandari SR, Kapadia AH. 1983. A 9,10-dihydrophenanthrene from tubers of Eulophia nuda.

[4] Bhandari SR, Kapadia AH, Mujumder PL, Joardar M, Shoolery JN. 1985. Nudol, a phenanthrene of the orchids Eulophia nuda, Eriacarinata, and Eriastricta. Phytochemistry (Oxford) 24 (4): 801-804.

[5] Choudhury S, Rahaman CH, Banerjee N. 2009. Studies on the leaf epidermal micromorphology, wood elements characters and phytochemical screening of three medicinally important taxa of the family Convolvulaceae. J. Environ. \&Sociobiol.6(2): 105-118.

[6] Shashidhar KS. 2013.Geodorum densiflorum- Plant of the Month. Bulletin of Orchid Society of Karnataka.

[7] Akter S, Iman ZI, Akter T. 2010. Antimicrobial activity of different extracts of Geodorum densiflorum (Lam.) Schltr. Pseudo bulb. Stanford journal of Pharmaceutical Science.2010; 3(2): 47-48 213 Journal of Pharmacognosy and Phytochemistry.

[8] Habib MR, Rana MS, Hasan MR, Iman MZ, Hasan SMR, Saha A.2011. Antioxidant, cytotoxicity, and Antibacterial Potential of different extract of Geodorum densiflorum (Lam.) Schltr. Root. Journal of Herbal Medicine and Toxicology. 5(1):63-70.

[9] Arditti J. 1967. Factors affecting the germination of orchid seeds. The Botanical Review33(1): 1-88.

[10] Keerthiga M, Anand SP. 2014. Physicochemical, Preliminary Phytochemical analysis and antibacterial activity against clinical pathogens of medicinally important orchid Geodorum densiflorum (Lam.) Schltr. International Journal of Pharmacy and Pharmaceutical Sciences. 6(8):558-61.

[11] Shrirama V, Kumar V, Kavi Kishore PB, Suryawanshi SB, Upadhyaye AK, Bhate MK. 2010. Cytotoxic activity of 9, 10-dihydro-2,5-dimethoxyphenanthrene-1,7-diol from Eulophia nuda against human cancer cells. Journal of Ethnopharmacology. 128:251-253.

[12] Yadav SR, Sardesai MM. 2002.Flora of Kolhapur District.

[13] Johansen DA. 1940.Plant Microtechnique. Mc Graw-Hill Book Company, Inc. New York.

[14] Maurya R, Dongarwar NM. 2009. Studies on some 
medicinal trees of Nagpur district with special reference to Pharmacognosy. M.Phil. Dissertation, Nagpur University, Nagpur.

[15] Sadasivam S, Manickam A. 1996. Biochemical Methods. New Age International Publishers.

[16] Harborne J.B. 1973. Phytochemical methods: A guide to modern techniques of plant analysis, 13th Ed. Chapman and Hall, Ltd. London, 1973; 5-15.
[17] Shekhar TC, Goyal A. 2014. Antioxidant activity by DPPH Radical Scavenging Method of Ageratum conyzoides Linn. Leaves. American journal of Ethnomedicine, Vol. 1, No. 4, 244-249.

[18] Das A, Pal KK, Nag S. 2018. Anatomy, micromorphology, and histochemical localization of different phytochemicals of two medicinally important taxa of the family Zingiberaceae. RJLBPCS 4(1): 191. 